DOI https://doi.org/10.30525/978-9934-588-46-4.05

\title{
PECULIARITIES OF THE PROFESSIONAL DEVELOPMENT MANAGEMENT OF LOCAL SELF-GOVERNMENT BODIES IN EU MEMBER STATES
}

\section{Kachan Ya. V.}

\section{INTRODUCTION}

In case of Ukraine establishes itself as a democratic, constitutional, social state, for it to develop civil society, to integrate EU standards, to reform the public service system, it is necessary to prepare a new generation of managerial and specialists of state and local selfgovernment bodies, to prepare staff to replace vacant positions in the structure of a local government. The success of state reforms and the implementation of the Action Plan aimed at implementing the State Personnel Policy Strategy for 2012-2020 in Ukraine depends on the professionalism of local government staff.

Ukraine, like most UN member states, has joined the global process of sustainable development. One of the goals of sustainable development in Ukraine is "to provide inclusive and equitable quality education and to promote lifelong learning for all". An important strategic direction of Ukraine's development in accordance with the Strategy for Sustainable Development "Ukraine 2020" and the Strategy for reforming the public administration of Ukraine for the period up to 2021, defines the modernization of the civil service on the basis of European principles that are put forward to the candidate countries for accession to the EU.

Thus, modernity shapes the need to create a highly professional institute of public service in our country, to provide the conditions in which it would function effectively with the help of skilled workers, capable of proper public policy implementation, timely response to any transformational challenge. In this regard, the need to study the current trends in managerial activity in relation to the professional development of the staff of local self-government structures and, in turn, to improve the domestic system of professional training of specialists of local selfgovernment bodies is becoming increasingly relevant.

Since Ukraine's strategic direction is a full membership in the European Union, research into the professional development experience of EU Member States staff such as the United Kingdom of Great Britain 
and Northern Ireland, the Republic of Poland and the French Republic may provide Ukraine with additional knowledge to improve management staff of its local self-government bodies.

\section{Institutional support for the professional development of local government personnel in Ukraine}

For many years, international organizations and their institutions (International Labor Organization - ILO, Organization for Economic Cooperation and Development - OECD, European Center for the Development of Vocational Education and Training - ECRPON, etc.) have conducted analytical research in the field of professional development of personnel.

The results of the work underpin the global policy guidelines of the global community in moving towards a knowledge-based society, including building an effective professional development policy for production staff as an integral part of national development strategies. The tasks identified in the Europe 2020 Strategy $^{1}$ have been further refined in a number of official EU documents, resolutions, recommendations, reports and programs of the European Council, the European Commission, the European Parliament, official national documents, etc. For example, the Bruges Communiqué on Strengthening European Cooperation in Vocational Education and Training for the period 2012-2020, adopted by the European Commission in conjunction with the Ministers responsible for this field in the Member States $(2010)^{2}$, has put on the agenda a modern and the future development of Europe, systematic introduction into all vocational education programs (school profile education, basic vocational education and training, continuing vocational education and training) of productive training. As stated in this strategic document, training on the basis of practical activity in the workplace is a means of personal capacity development, promotes the stability of professional identity development, increases self-esteem, enables you to develop your own potential while maintaining income, and so on. "Well-regulated vocational education

${ }^{1}$ Europe 2020. A strategy for smart, sustainable and inclusive growth. URL: http://ec.europa.eu/eu2020/pdf/COMPLET\%20EN\%20BARROSO\%20\%20\%20007 $\% 20-\% 20$ Europe\%202020\%20-\%20EN\%20version.pdf.

${ }^{2}$ European Commission. Communiqué of the European Ministers for Vocational Education and Training, the European Social Partners and the European Commission, convened in Bruges on 7 December 2010, on enhanced European Cooperation in Vocational Education and Training for the period 2011-2020. URL: http://www.bruges_en.pdf. 
and training in and outside manufacturing will promote social cohesion in our societies",

With the signing of the political (21 March 2014) and economic (27 June 2014) parts of the Association Agreement between Ukraine, on the one hand, and the European Union, the European Atomic Energy Community and their Member States, on the other ${ }^{4}$, which came into force on September 01, 2017, the strategic direction of our country's movement fully and legally elected full membership of Ukraine in the European Union. The process of European integration requires approximation of the state institutions of power to the EU standards and principles.

The basis for Ukraine's European integration should be a reformed civil service based on the principles of democracy, legality, competence, professionalism, honesty, initiative, openness, efficiency and coherence.

It should be noted that, in accordance with Article 48 of the Law of Ukraine "On Civil Service", enhancing the professional competence of civil servants creates the necessary conditions for civil servants to improve their professional competence through continuous vocational training. Also, Article 48 states that the professional training of civil servants shall be carried out at the expense of the state budget and other sources not prohibited by the legislation, in accordance with the needs of the state authority, through the system: training, retraining, specialization, and professional development in educational establishments, institutions, organizations, regardless of ownership, who have the right to provide educational services, including abroad ${ }^{5}$.

Professional training of civil servants and officials of local selfgovernment means that they obtain a master's educational qualification level, as well as undergo postgraduate studies, doctoral studies, study at universities or scientific institutions, acquiring specialties that provide professional activity within the civil service and in the structure of government; the essence of retraining is to obtain a specialty in

3 Пуховська Л.П., Ворначев А.О., Леу С.О. Професійний розвиток персоналу підприємств у країнах Європейського Союзу : посібник / за наук. ред. Л.П. Пуховської. Київ : ІПТО НАПНУ. 2015. 176 с.

${ }_{4}^{4}$ Угода про асоціацію між Україною, 3 однієї сторони, та Європейським Союзом, Свропейським Співтовариством з атомної енергії і їхніми державамичленами, з іншої сторони, від 27.06.2014. Офіu. сайт Верховної Ради України. URL: http://zakon3.rada.gov.ua/laws/show/984_011/paran2820\#n2820.

5 Про державну службу : Закон України від 10.12.2015 № 889-VIII / Верховна Рада України. Законодавство України. URL: http://zakon0.rada.gov.ua/ laws/show/889-19. 
accordance with the direction of preparation of "Public administration and administration" and specialties, which envisage professional activity within the civil service and in the structure of local self-government bodies, based on previously acquired educational qualification level and gained practical experience; specialization is distinguished by the acquisition of the necessary educational and qualification level in a certain specialty, which involves professional activity within the civil service and in the structure of local self-government bodies. Upgrading means obtaining the education to upgrade and acquire the skills, knowledge, skills and ability to perform the tasks and responsibilities necessary for professional activity within the civil service and within the structure of local self-government bodies.

If, in order to improve the professional competence of a civil servant, according to the law, he/she may receive an internship, leaving the service for a term of 1-6 months and transferring to another position in public service within the structure of another state body or outside the country. As long as an employee is practicing, his or her position and salary is saved.

Article 49 of the Law of Ukraine "On Civil Service" provides in particular for an individual program for enhancing the professional competence of a civil servant. Accordingly, a civil servant, on the basis of the performance appraisal, together with the HR department, draws up an individual professional development program, which must be agreed upon by his/her direct supervisor and the head of the independent structural unit in which he/she works - approve this program ${ }^{6}$.

In recent decades, a competent approach in the education system has become necessary in every field, in particular as regards the training and professional development of civil servants. Today, there is an active reform of the national system of state government, which undergoes a number of complex and controversial processes. It is the competent managers who can influence how effectively the system will be reformed and the professionalism of civil servants improved.

The main position and leading role in the structure of the education system of training civil servants belongs to the National Academy of Public Administration under the President of Ukraine, which is engaged in training, retraining and advanced training of civil servants and officials working in local self-government.

6 Про державну службу : Закон України від 10.12.2015 № 889-VIII / Верховна Рада України. Законодавство України. URL: http://zakon0.rada.gov.ua/ laws/show/889-19. 
Strategic priorities for the development of the National Academy are:

- strengthening of the educational position of the National Academy as a leader in the training, retraining, specialization and advanced training of public servants, as well as in the training of Ph.D in the field of knowledge "Public administration and administration";

-strengthening of the scientific-expert position of the National Academy as a leading scientific-methodical, expert-analytical and advisory center, which carries out scientific support of the activity of the President of Ukraine, conducts research at the request of public authorities, carries out expert examination of policies and gives recommendations on their implementation;

-formation in the National Academy of Legal, Organizational, Information-Communication, Logistics, Financial and Other Conditions for Study, Teaching, Scientific Research, Writing of Current Publications in the Field of Public Administration and Administration ${ }^{7}$.

Also, in order to improve the qualification of civil servants of different departments, licensed sectoral higher education institutions of Ukraine and postgraduate educational institutions are licensed.

Civil servants can upgrade their qualifications at the All-Ukrainian Center for Advanced Training of Civil Servants and Officials of Local Self-Government, which is an institution of postgraduate education that belongs to the sphere of management of the National Agency of Ukraine for Civil Service.

From the National Academy, four regional institutes and three educational and scientific institutes, higher educational establishments in which bachelors and masters in the field of "Public administration and administration", centers of retraining and improvement of qualification level of employees, branch institutes of qualification level improvement belonging to a nationwide education system designed solely to provide training, retraining and advanced training for civil service of the children. The area of its activity is the whole of Ukraine, every power branch and every body of local self-government, as well as every level of professional training, scientific and methodological support of public service and personnel decisions.

We should refer to the studies of K. Magomedov, B. Ponomarenko and V. Sulemov, who emphasize the peculiarities of the implementation

7 Стратегія розвитку Національної академії державного управління при Президентові України на 2017-2021 роки від 24.11.2016 № 240/11-1 : Рішення вченої ради Національної академії. URL: http://academy.gov.ua/?lang=ukr $\&$ tip $=$ dop $\&$ tipn $=$ Page $\&$ page $=80$. 
of certain elements of the system of professional development of personnel, in particular:

- lack of a strategy in the field of personnel professional development at the level of a separate local government body;

-low level of development of normative, legal and organizational bases for professional development of local government staff;

- poor motivation of employees and heads of local self-government bodies;

-insufficient regulation and low efficiency of activity of personnel management services;

-low responsibility of personnel management services for the organization of professional development of local self-government personnel;

-weak connection of additional vocational education with the practical needs of the local government;

-slow mastering of modern technologies of management of professional development of personnel;

-ill-considered use of foreign experience of professional development and professionalization of personnel ${ }^{8}$.

Thus, the processes of intensive ongoing professional training and development of the necessary theoretical framework, practical knowledge and skills designed to help local government workers adapt to the fact that internal and external state policies are undergoing constant changes and create new challenges, improve management services and not transformed management services. on priority directions in the educational movement. Therefore, it should be noted that as a result of this approach to such education, there is a lack of relevant and contemporary public sector career training for managers who are highly skilled, strategically minded, competitive in the labor market, responsible for building an effective European public administration in our country.

\section{Organization of staff professional development of EU Member States local self-government bodies}

Local government staff in different countries have different legal status. There are significant differences in the rights and obligations of public servants, in particular in the Member States of the European

${ }^{8}$ Магамедов К.О., Пономаренко Б.Т., Сулемов В.А. Кадровая коррупция в системе государственного управления: социологический мониторинг : монография. Москва : Реал Принт, 2015. 
Union and in the candidate countries. This has to do with the impact on the civil service of both internal and external factors.

International experience is rich in practice, where civil servants are employed in senior management with tools to evaluate performance and pay for outcomes that are highly relevant to the professional evolution of public servants. If a government agency successfully completes the task, its manager is entitled to an additional remuneration, and if the opposite is the case, he or she may be dismissed or dismissed. However, in the countries representing the Organization for Economic Cooperation and Development (OECD), there is a perception that performance management should be more focused on career development and career growth, rather than on the possibility of an immediate increase in salary or bonuses.

Today, most EU countries are improving the staffing of public service, including delegating the functional duties of civil servants, decentralizing and individualising them. There is a widespread assumption among the Member States of the European Union that by giving power and motivation to managers, increasing their powers and responsibilities, they can significantly improve their performance.

The European Union has accumulated tremendous experience in reforming and improving public administration and public service, despite the fact that public administration is not covered by the acquis communautaire 9 . The most important developments include:

- defining "European principles of public administration";

- defining "principles of European administrative law";

-the introduction and definition of the term "European Administrative Space";

-wider use of the concept of "European governance" as a multi-level governance system in a multi-vector system, consisting primarily of European institutions and national local governments, involving local self-government and civil society, with involvement of international experts and lobbyists.

-the introduction of the term "Europeanization", which, in the area of public administration, means drawing on the experience and implementation of best management practices of EU bodies or Member States in national systems of public administration, adapting national procedures, norms and standards to EU norms and rules.

${ }^{9}$ Acquis communautaire. URL: https://ec.europa.eu/agriculture/glossary/acquiscommunautaire_en_en. 
The public service of the French Republic is one of the most stable and organized in the world and is considered to be the standard of organization and implementation of public-service relations for the modern state. Unlike France, the United Kingdom and Northern Ireland have strong traditions of self-government within the unitary system of administrative and public administration. The system of public administration of the Republic of Poland is formed on the example of the public service of France, besides Poland is one of the closest neighbors of Ukraine, and also became an example in the decentralization reform for our country.

In 1981, the European Institute of Public Administration (EIPA) was established $^{10}$ to provide high quality training courses to develop the capacity of experts, national and regional state administrations of EU Member States and European institutions. The main areas of work of EIPA include: decision making in the EU, EU policy, public administration in the EU, European Union law, regional affairs.

EIPA is an independent institute with a Supervisory Board composed of representatives of EU Member States and associated EIPA members. The mission of the representatives is to maintain a permanent link between the Institute and national public institutions and to ensure a strong institutional network at the highest level of government throughout Europe.

The European School of Administration ${ }^{11}$ was established by EU institutions in 2005 to expand the range of training and development opportunities available to their staff - public servants. Training policy provides for a more general mechanism for developing the competences of public servants and thus contributes to the higher effectiveness of public service.

When comparing the public service systems of different Member States of the European Union, there are two categories - the closed (career) and open (official) systems. However, it should be noted that none of these categories is used in its purest form in any country.

The closed system uses a multifunctional approach when selecting candidates for public service. Preparing candidates for employment in a closed system is a necessary part of the selection process. It is widely used in Greece, Slovakia, Poland and France. An example is the Lech

${ }^{10}$ European Institute of Public Administration. URL: http://www.eipa.eu/en/ pages/display/\&tid=3.

11 The European School of Administration. URL: http://europa.eu/eas/ index_en.htm. 
Kaczynski National School of Public Administration (Krajowa Szkoła Administracji Publicznej im. Prezydenta Rzeczypospolitej Polskiej Lecha Kaczyńskiego - KSAP) ${ }^{12}$ in Poland, which provides a two-year preparatory program for candidates for public service. It was modeled after the French National School of Management (École nationale d'administration $-\mathrm{ENA}^{13}$ ).

An open system involves the admission of employees to specific positions that require specific professional knowledge.

In countries such as Germany, Austria, Switzerland, a dual system of vocational training for workers is used, covering approximately $75 \%$ of the population. Such a system is advantageous for enterprises, because they receive enough students, save on pay, and can select the best employees for permanent work after graduation.

In Germany and France, access to a public service involves long-term training in specialized institutions such as the Federal Academy of Public Administration and the National School of Public Administration. In other countries, such as the UK, it is not necessary to have a specific education, but to have a certain level of education to enter public service. However, in this case, the workplace adaptation system plays an important role as soon as it is hired.

Considering such an EU Member State as the United Kingdom, public officials are primarily politicians, including the Prime Minister, all Ministers, Permanent Secretaries of Ministries, their Deputies and Deputy Assistants.

The Vocational Training System in the United Kingdom is overseen by the Public Service Commission and the Public Service Capability Training and Development Board. The main educational institution in the field of public administration is the National School of Government (since 2012 - the School of Public Administration, Civil Servise Learning $)^{14}$.

The School of Public Administration is responsible for the preparation and teaching of the training courses, and the Public Service Affairs Commission is already recruiting for the public service. A major prerequisite for entry into public service is a general-purpose written exam based on programs from the leading universities in the UK -

12 Krajowa Szkoła Administracji Publicznej im Prezydenta Rzeczypospolitej Polskiej Lecha Kaczynskiego. URL: http://ksap.gov.pl/ksap/.

${ }^{13}$ Ecole Nationale d'Administration. URL: https://www.ena.fr/eng/ENGLISH.

${ }^{14}$ Centre des études européennes de Strasbourg. URL: www.cees-europe.fr/. 
Oxford and Cambridge. Graduates of these universities have a high chance of occupying senior positions in the public service ${ }^{15}$.

The entire recruitment, training and promotion system in the UK is organized to create the type of professional manager, generalist administrator. Well-known English political scientist D. Steel believes that in the UK, "experts" are little suited for administrative work. A successful administrator, D. Steele points out, must be neutral to a particular problem, but with knowledge and experience, he is required to strike a balance between different interests.

The French civil service is considered to be very stable and organized, and therefore it is a certain benchmark for how civil service relations in a modern state should be organized and implemented. Public officials are officials who, in their actions, at the same time represent the state and serve its interests. French officials are a special social layer. They are given a permanent position, are included in the staff and receive a rank within the administrative hierarchy.

France has a closed career path. Its content is that the legal status of an employee takes into account the peculiarities of the country, and that is why the civil service is governed by administrative and legal norms and the totality of civil service rights. The guiding principle of such a system is the desire to ensure that a person becoming an employee no longer leaves the service until the retirement, making a gradual move through official stages.

The basic principles in the work of a French public servant are: full commitment to professional activity, moral principles, restraint, hierarchical humility, professional diligence, honesty, neutrality.

Failure to adhere to the principles can lead to disciplinary sanctions, which also apply to dismissed public officials ${ }^{16}$.

Also, the basic principles of public service in France, contained in the General Statute of the public service and on the basis of which a number of traditions have been created, include:

1. Principles of entry into public service: competitive selection guarantees a level playing field for everyone.

15 Managing Senior Management: Senior Civil Service Reform in OECD Member Countries. Background Note. URL: https://www.oecd.org/gov/pem/ 33708901.pdf.

${ }^{16}$ Світові моделі державного управління: досвід для України / за заг. ред. Ю.В. Ковбасюка, С.В. Загороднюка, П.І. Крайніка, Х.М. Дейнеги. Київ : НАДУ, 2012. $612 \mathrm{c}$. 
2. Career advancement: A future public servant is fully entitled to a seniority-based career.

Pre-requisite education is compulsory. Only after the successful completion of the educational institution is the appointment of a public servant. In order to qualify for a senior position, you must have a minimum of four years' service experience.

The Directorate General of the Civil Service (DGAFP) is the central body responsible for the policy of professional training for the national public service; The Main Directorate for Local Authorities in the Ministry of the Interior is responsible, in turn, for the policy of training the personnel for the territorial public service.

DGAFP provides overall coordination of civil servant training policies, which contains the legal framework and agreements with civil servants associations. The Civil Service Department is also responsible for the policy of training senior civil servants. In particular, he is supervised by the Higher School of Public Administration (ENA) and 5 IRAs (Regional Institutions of Administration). Within the competence, each Ministry is also responsible for the development of policies for the training of public servants. DGAFP also focuses on an interdepartmental network of managers trained in management training.

Ecole National d'Administration (ENA) is the main French civil service training institution. ENA is a world-renowned institution and its experience in the field of management training is followed by many professional public service institutions in the world. It was created by a decree of the Provisional Government of the French Republic, headed by General de Gaulle, on October 9, 1945 to implement the program of the National Council of Resistance, to democratize and unify ways of training senior officials, namely:

- unifying the recruitment of public servants to prepare them for careers in various areas of public administration;

- providing uniform training for all top-level officials ${ }^{17}$.

The purpose of the ENA is to train public officials who would transform the civil service into a genuine institution of government and be able to meet the challenges of today and the growing needs of citizens. ENA trains senior general executives.

In addition to senior management, ENA trains civilian leaders (officers) and officers who leave military service. Top-level executives

${ }^{17}$ Світові моделі державного управління: досвід для України / за заг. ред. Ю.В. Ковбасюка, С.В. Загороднюка, П.І. Крайніка, Х.М. Дейнеги. Київ : НАДУ, 2012. $612 \mathrm{c}$. 
are promoted to careers and undergo a "senior management improvement cycle". It lasts 7 months. Officers who have left military service may be assigned as "civilian leaders" or supereffects. Their retraining lasts for 2 months and is called the "officer integration cycle"

The senior civil service is trained by the Institut national des études territoriales (INET), where the training lasts for 18 months. Mid-level public officials have the opportunity to receive training at five Regional Institutions of Public Administration (IRA) located in Bastia, Lille, Lyon, Metz and Nantes. The training of high-level officials dealing with pan-European issues is carried out at the Center for European Studies (CEES) of Strasbourg ${ }^{19}$.

In addition, there are 44 specialized educational institutions in France, subordinate to different ministries that train specialists in different professions in the public service, who provide compulsory basic courses for the acquisition of competencies and professional development. All public servants of France are upgraded throughout their careers on a continuing education basis.

In Poland, the National School of Public Administration was established by decision of the Council of Ministers of 30 May 1990. The status of this institution is governed by the Law of 14 June 1991, as well as the Statute agreed by the Prime Minister of 23 August $1991^{20}$.

The educational program of the National School of Public Administration is multidisciplinary and focuses mainly on the development of practical skills. A compulsory internship program is one component of the school curriculum, which plays an important role for students (one internship takes place in Poland, a ministry or central institution, and the other abroad, in the administrative institutions of countries such as the US, France, Germany or United Kingdom). The purpose of the internship program is to familiarize students with the latest trends in public administration in the highly developed countries ${ }^{21}$.

According to Article 36 of the Law on Public Service, the preparatory service is aimed at the theoretical and practical training of an employee

18 Côme Thierry, Rouet Gilles. Statuts des personnels, gouvernance et justice organisationnelle. Le cas des universités françaises, Revue Interdisciplinaire Management, Homme \& Entreprise. 2017. № 4 (28). P. 77-89. URL: https://www.cairn.info/revue-rimhe-2017-4-page-77.htm.

${ }^{19}$ Centre des études européennes de Strasbourg. URL: www.cees-europe.fr/.

${ }^{20}$ Krajowa Szkoła Administracji Publicznej im Prezydenta Rzeczypospolitej Polskiej Lecha Kaczynskiego. URL: http://ksap.gov.pl/ksap/.

21 Krajowa Szkoła Administracji Publicznej im Prezydenta Rzeczypospolitej Polskiej Lecha Kaczynskiego. URL: http://ksap.gov.pl/ksap/. 
who begins to work in the public service for the first time in the proper performance of his or her professional duties. It is important that such training does not focus solely on a special position in the selected unit, but on the public service as a whole.

The Director General of the institution organizes the preparatory service. The preparatory service lasts for four months and ends with the examination no later than 8 months from the date of employment.

Graduates of the National School of Public Administration are exlege exempt from the preparatory service. The release is unconditional, so it also covers the final exam. According to the legislation, conditional release from the preparatory service may be granted by the Director General of an institution to an employee at the request of the head of the organizational unit in which the employee works. However, such exemption does not apply to the final examination ${ }^{22}$. After the employee has passed the preparatory service and passed the examination, the Director General of the institution makes the decision to conclude the contract for an unlimited period of time. However, the CEO is under no obligation to enter into such an agreement, even if the result of the examination is positive.

The system of periodic assessments covers all members of the Civil Service Corps who are employed under a permanent contract. This follows from Article 81 of the Law on Public Service, according to which "a civil servant and a public service employee working under a fixed-term employment contract are subject to periodic examinations conducted by her/his manager". In the case of the evaluation of the Director-General, the evaluation shall be carried out by: the Prime Minister's Office, the Minister responsible, the chairman of the Committee of Ministers, the Head of the Central Government Office or a regional (governorate) governor.

The list of duties of a member of the Public Service Corps includes the obligation to improve professional knowledge. The manner in which this obligation is fulfilled is governed, first and foremost, by Articles 106-112 of the Law on Public Service. In accordance with Article 106, paragraph 2, public service training covers: central training; general education; training in individual programs of professional development of a member of the Public Service Corps; specialized trainings.

22 Mroczka K. Wyzwania modernizacyjne służby cywilnej w Polsce / Administracyjne prawo ustrojowe. Rocznik administracji publicznej. 2016. Vol. 2. 22 p. URL: http://www.ejournals.eu/sj/index.php/RAP/ article/view/6735/6657. 
General training is organized to develop the knowledge and skills of members of the Public Service Corps that are necessary for the correct performance of public service tasks and include, in particular, administrative law, public finances, standards of productive and effective work in public administration, or ethics in public administration.

Specialized training is also provided for those holding specialist positions in order to deepen their knowledge and skills in the areas related to the tasks of the institution.

The legislation obliges employers to determine individual professional development programs for members of the Public Service Corps, which will serve as a basis for sending employees for training, taking into account, in particular:

- the conclusions of the periodic assessment,

- public employee promotion and bonus roadmap,

- professional development plans and opportunities,

- needs and opportunities of the institution within the framework of employment.

The individual professional development program of a public servant is carried out through participation in central, general or specialized training, provided that the training programs correspond to their individual professional development program.

In addition to employment on the basis of an employment contract, there is another form of establishing employment relations - on the basis of appointment. Appointment to a public service position is a separate administrative act issued by a body that certifies that a public service employee fulfills certain requirements. As J. Itrich-Drabarek emphasizes, hiring an employee is, in fact, a specific manifestation of the will of the state $^{23}$.

According to Article 40 of the Law on Public Service, a person who:

-is a public service employee;

- has at least three years of public service experience or has received the approval of the Director-General of the institution to participate in the qualification procedure before the expiration of the prescribed period, but no earlier than two years from the date of his employment in the public service;

- has a master's degree or equivalent;

23 Krajowa Szkoła Administracji Publicznej im Prezydenta Rzeczypospolitej Polskiej Lecha Kaczynskiego. URL: http://ksap.gov.pl/ksap/. 
-knows at least one foreign language from the list of working languages of the European Union and at least one of the following languages: Arabic, Belarusian, Chinese, Icelandic, Japanese, Norwegian, Russian, Ukrainian;

- is a reserve soldier or not subject to compulsory military service.

The fulfillment of the above conditions is confirmed by the DirectorGeneral of the institution on the basis of documents held at the institution or submitted by the employee applying for appointment.

If an employee hired through an employment contract has been promoted to a position, then his or her employment relationship becomes the basis on which the appointment is based. There is only a change in the basis of employment. The other elements that are in the contract (whether it is a job, rem place, reward or position) do not change.

\section{CONCLUSIONS}

Thus, it can be argued that the policy of European states, whose essence is vocational education and training, adheres to a promising trend towards convergence of professional education with the labor market, including by forecasting the needs for professional skills/competences and using such methods and tools as: making predictions about which occupational profiles and professional skills in different types and levels of professional activity will be required; a complex of labor market information systems and employment service analytics; an analytical study of how effectively educational institutions operate; a method of retrospective analysis, the object of which is the career of graduates, the state of social partnership, etc.

If we talk about the optimal policy in vocational education and training, in the EU countries we can clearly see such a promising trend the process of social partnership in the framework of vocational training and development of industrial personnel, which is manifested in the fact that:

-increasing professional competence and mobility,

-increased productivity and wages,

- economic indicators are increasing,

- full self-development and self-realization of specialists is ensured.

As stated in the strategic documentation, having strong employeremployee partnerships between the state is a crucial indicator of the interaction between education and work as a sphere of social life.

In addition, it should be noted that the system under which employees are hired, trained and promoted in the UK is organized in such a way as 
to create the type of highly professional manager, administrator with a wide profile (France is characterized by the dominance of a similar concept). The French career system is closed and oriented so that the person, having become an employee, no longer leaves the service until the retirement, making a gradual move through the service. Every French public servant has been upgrading his/her career throughout his/her career, constantly studying. The basic principles of vocational training include the following principles: continuity of the educational process, quality level of education, approximation of training with the workplace, optimality of education costs. The Polish vocational education system has a compulsory internship program, which is an integral part of the school curriculum, which is important for students. Of the two internships, one takes place in Poland, within a ministry or headquarters, and the other in a foreign administrative office in the United States, France, Germany or the United Kingdom. The internship program aims to introduce students to a number of recent trends in public administration in advanced countries.

\section{SUMMARY}

The specificity of legal regulation of professional growth of employees of local self-government structures is analyzed. It is clarified that the system according to which the quality of vocational education of local government employees is monitored and evaluated in order to be in line with EU norms and standards, to establish an effective system for determining the professional training needs of local self-government, should be standardized, continuity, obligation, planned professional training of civil servants, development of the market of educational plan services in the segment of vocational education of employees transparent and fair competition. Theoretical provisions concerning the deployment of professional education systems of government employees in our country have been improved. Traditional and constructivist approaches were applied.

The main components of the latest paradigm of professional development of local government workers in the Ukrainian state are identified. They envisage the following tasks: to identify new forms of professional growth of local self-government personnel; to define clear indicators and criteria according to which the competence of employees of local self-government structures will be evaluated; to ensure a permanent link between the results of professional training and the promotion of career paths of local government employees; legislatively regulate the short and long-term goals of professional development of 
staff of local self-government bodies; to distinguish individual components in the system of vocational education of local selfgovernment officials and principles of their training, taking into account the European experience, the main of which are: transfer of new basic knowledge for each, updating of the assessment system, purposefulness, forward-thinking nature and predictability, practical orientation.

\section{REFERENCES}

1. Магамедов К.О., Пономаренко Б.Т., Сулемов В.А. Кадровая коррупция в системе государственного управления: социологический мониторинг : монография. Москва : Реал Принт, 2015.

2. Про державну службу : Закон України від 10.12.2015 № 889-VIII / Верховна Рада України. Законодавство України. URL: http://zakon0.rada.gov.ua/laws/show/889-19.

3. Пуховська Л.П., Ворначев А.О., Леу С.О. Професійний розвиток персоналу підприємств у країнах Європейського Союзу : посібник / за наук. ред. Л.П. Пуховської. Київ : ІПТО НАПНУ. 2015. $176 \mathrm{c}$.

4. Світові моделі державного управління: досвід для України / за заг. ред. Ю.В. Ковбасюка, С.В. Загороднюка, П.І. Крайніка, Х.М. Дейнеги. Київ : НАДУ, 2012. 612 с.

5. Стратегія розвитку Національної академії державного управління при Президентові України на 2017-2021 роки від 24.11.2016 № 240/11-1 : Рішення вченої ради Національної академії. URL: http://academy.gov.ua/?lang=ukr\&tip=dop\&tipn=Page \&page=80.

6. Угода про асоціацію між Україною, 3 однієї сторони, та Свропейським Союзом, Свропейським Співтовариством з атомної енергії і їхніми державами-членами, з іншої сторони, від 27.06.2014. Oфіu. сайт Верховної Ради Украӥни. URL: http://zakon3.rada.gov.ua/ laws/show/984_011/paran2820\#n2820.

7. Acquis communautaire. URL: https://ec.europa.eu/agriculture/ glossary/acquis-communautaire_en_en.

8. Centre des études européennes de Strasbourg. URL: www.ceeseurope.fr/.

9. Côme Thierry, Rouet Gilles. Statuts des personnels, gouvernance et justice organisationnelle: Le cas des universités françaises. Revue Interdisciplinaire Management, Homme \& Entreprise 2017 № 4 (28). P. 77-89. URL: https://www.cairn.info/revue-rimhe-2017-4-page77.htm.

10. Ecole Nationale d'Administration. URL: https://www.ena.fr/ eng/ENGLISH. 
11. Europe 2020. A strategy for smart, sustainable and inclusive growth. URL: http://ec.europa.eu/eu2020/pdf/COMPLET\%20EN\% 20BARROSO $\% 20 \% 20 \% 20007 \% 20-\% 20$ Europe $\% 202020 \% 20$ $\% 20 \mathrm{EN} \% 20$ version.pdf.

12. European Commission. Communiqué of the European Ministers for Vocational Education and Training, the European Social Partners and the European Commission, convened in Bruges on 7 December 2010, on enhanced European Cooperation in Vocational Education and Training for the period 2011-2020. URL: http://www.bruges_en.pdf.

13. European Institute of Public Administration. URL: http://www.eipa.eu/en/pages/display/\&tid=3.

14. Krajowa Szkoła Administracji Publicznej im Prezydenta Rzeczypospolitej Polskiej Lecha Kaczynskiego. URL: http://ksap.gov.pl/ksap/.

15. Managing Senior Management: Senior Civil Service Reform in OECD Member Countries. Background Note. URL: https://www.oecd.org/gov/pem/33708901.pdf.

16. Mroczka K. Wyzwania modernizacyjne służby cywilnej w Polsce. Administracyjne prawo ustrojowe. Rocznik administracji publicznej. 2016. Vol. 2. 22 p. URL: http://www.ejournals.eu/sj/ index.php/RAP/article/view/6735/6657.

17. The European School of Administration. URL: http://europa.eu/eas/index_en.htm.

\section{Information about author:} Kachan Ya. V.,

Ph.D. in Public Administration, Assistant Professor of Public Management and Administration Department Ukrainian State Employment Service Training Institute 17, Novovozalnaya Str., Kyiv, 03038, Ukraine 